\title{
Does importing more inputs raise productivity and exports? Some evidence from Indian manufacturing
}

\author{
Chandan Sharma ${ }^{1}$
}

\begin{abstract}
This study aims to analyse the role of imported inputs on productivity and export performance of the manufacturing industries of India. Our results indicate that imported inputs are crucial determinates of Total Factor Productivity (TFP). However, the impact varies greatly across industries. Furthermore, results regarding research and development $(R \& D)$ intensity suggest that inhouse R\&D activities do not play a significant role in the productivity performance of Indian manufacturing firms. Our results also indicate that imports lead to a substantial growth in exports. In particular, exports in the chemical, machinery and transport equipment industries are highly dependent on imported intermediate goods. The results also indicate that although $R \& D$ is not linked with the productivity of industries, it has an important role in the export performance of these industries. TFP is also estimated to have a significant and sizable impact on export performance. This, in turn, supports the self-selection hypothesis, which explains the self-selection of more productive firms into the export market. Overall, our results support both hypotheses: learning by importing and self-selection in the import market.
\end{abstract}

\section{INTRODUCTION}

T mported inputs are considered a crucial factor in various trade and growth models. These models advocate that firms gain from international trade in general, and imports in particular, through better access to otherwise unavailable inputs. The gain for firms from importing could be static and dynamic (e.g. see Coe and Helpman 1995; Barro 1997; Frankel and Romer 1999). The use of imported inputs has also increasingly become a channel for obtaining new technologies, which in turn enhances industrial productivity. Since developing countries lack in original research and development (R\&D), 
the adoption and simulation of technologies through the import route has become a crucial source of technological enhancement in these countries.

However, empirical findings on this issue are very mixed. For example, recent studies by Amiti and Konings (2007), Jones (2008), Kasahara and Rodrigue (2008), Goldberg et al (2010), Sharma (2014) and Halpern et al (2015), have found a significant role for imports or imported intermediate inputs in explaining the productivity growth of domestic firms. Contrary to this, Lawrence and Weinstein (1999), Van Biesebroeck (2003), and Muendler (2004) have shown insignificant or modest impacts from this activity.

In recent years, imported inputs have become a key source of high export growth, especially for developing countries. For instance, Hummels et al (2001) have shown that vertical integration accounted for 21 per cent of emerging countries' exports. The findings of Anós-Casero and Astarloa (2010) suggested that the contribution of imported inputs was around 14.5 percent in Argentina's total exports in the year 1997. Recently, Lo Turco and Maggioni (2013) for Italian manufacturing, and Aristei et al (2013) for European countries, found a crucial dependency of exporting on importing. In the theoretical literature too, the export-import linkage is widely discussed and shown to be strongly interlinked (e.g. Herander and Thomas 1986; Wonnacott and Wonnacott 2005). However, in the case of India, one of fastest and largest emerging economies, the issue is under-represented in the standard literature. Thus, given a solid theoretical inter-linkage between importing and exporting, there is a need to explore the role of imported inputs in the country's export performance.

This issue is important from a policy standpoint, as several economists in the country have proposed pursuing an export-oriented trade policy, especially through exchange rate intervention (for a detailed discussion, see Bhanumurthy and Sharma 2013). Some researchers (e.g. Lawrence and Weinstein 1999) argue that because of a lack innovation activities in the industries of developing countries, imported goods are an important source of learning. Imports also perform a crucial role in determining the export performance of industries. Therefore, a currency depreciation aimed at augmenting the exports and restricting the imports of a country, will not serve any great purpose, as exports are vitally dependent on imports.

Against this backdrop, we have twin objectives in this study. First, we test the effects of imported inputs on productivity. Second, we analyse the role of imported inputs on the export performance of the country. For the productivity-enhancing effects of imports, we test 'learning-by-importing'; and for more productive effects on importing, we examine the 'self-selection' hypothesis (for details, see Vogel and Wagner 2010). In doing so, we introduce several novelties. First, while the related literature on India is focused mainly on the export-productivity linkage (e.g. see Sharma and Mishra 2011), we focus on import-productivity and import-export linkages. Our findings will therefore be helpful in designing more beneficial exchange rate, trade and industrial policies. 
Furthermore, to promote exports through imported inputs, the government has given several exemptions on duties for exporters in India importing inputs (see FTP 2009). Over time, observers and experts have raised questions on the relevance and effectiveness of such policies and schemes (e.g. Topalova and Khandelwal 2011), as it is argued that this hurts local industries and causes revenue loss. Our findings will help in understanding the relevance of such policies. Second, in most of the previous studies in this area focusing on India, data from the annual survey of industry (ASI) database have been used. We utilise a relatively new manufacturing database, Prowess, which includes firm level data for eight important industries. It also allows us to extend the time horizon of the study up to 2011. This dataset is rich and provides detail on heterogeneity in terms of trade and R\&D across industries as well as over time. Considering the attractive properties of this database, some recent studies, e.g. Goldberg et al (2010), De Loecker et al (2012) and Sharma (2014), have used this database.

However, instead of using firm-level data, we opt for the industry-level data for the analysis as we are interested mainly in understanding the relationship at the industry-level (aggregate-level). By doing so, we are able to consider all firms in the database (more than 15000) in the analysis, while studies using firm-level data have been restricted to using a much smaller sample size because of data related constraints, such as, missing information on number of workers of a large number of firms. Furthermore, the main advantages of a firm-level analysis are the use of important information of firms such as entry-exit, competition and pricing. Prowess, however, does not provide this information. Therefore, the use of aggregate, industry-level data, seems to be advantageous in our case. Third, most of the previous studies have directly applied ordinary least squares (OLS) and have not paid serious attention to the time series properties of the temporal data i.e., (non-) stationarity of the variables, which can result in biased results.

Therefore, given the well-known fact that non-stationarity of data series causes various estimation problems, we utilise unit root tests and cointegration techniques to test the integration between variables in the panel context. For the estimation, we use Fully Modified OLS (FMOLS) and System Generalised Method of Moments (Sys-GMM), which are likely to produce better results than the traditional estimators, by taking care of endogeneity problems in the estimation analysis. It also allows us to use the variables in the level form in the analysis rather than their growth rates and therefore, avoids any information loss form the use of first differences. Finally, the recent trends suggest that the government is specifically focusing on enhancing R\&D activities by providing a series of fiscal incentives and financial support. Therefore, it is important to know the role of $R \& D$ in productivity enhancement as well as on exporting performance.

The rest of the paper is organised as follows: Section 2 presents the background theory and review of the literature. Section 3 discusses data-relat- 
ed issues and TFP estimation methodology. Section 4 discusses empirical models and methodologies. In Section 5, we discuss our empirical results. Finally, section 6 presents the main findings and conclusions of the study.

\section{THE THEORETICAL LINKAGE AND REVIEW OF THE RELATED LITERATURE}

A growing body of theoretical work, well supported by empirical studies in international economics, suggests that foreign trade has large positive effects on income, output and productivity (Romer 1987; Coe and Helpman 1995; Barro 1997; and Frankel and Romer 1999). The role of imported intermediate inputs is understood to be particularly vital and that is why, in recent years, it has attracted considerable attention in the standard literature: how do intermediate goods affect productivity? Importing and the performance of industry are integrated in several ways. First, better and easier access to imported intermediates can improve performance and productivity, because foreign intermediate inputs are generally of better quality. Second, it can also improve productivity through the production equivalent of a 'love-of-variety' (Ethier 1982). Third, endogenous growth models emphasise the important role of importing new varieties of inputs. It is shown in the theoretical literature that new varieties of inputs lead to a significant productivity improvement of firms, both in the short as well as in the medium term (Romer 1987; RiveraBatiz and Romer 1991). Fourth, foreign competition in the final goods market can also augment the productivity of domestic producers attributable to an Xinefficiency effect: trade yields welfare gains by inducing an increased supply of a non-contractible factor, which initially is socially under-supplied (e.g. Horn et al 1995).

Fifth, a decline in the prices of intermediate inputs may lead to a decrease in the markup accompanied by a scale effect (Krugman 1979; Helpman and Krugman 1985; Bernard et al 2003). Sixth, an increase in the speed of technology adoption through a reduction in the number of domestic firms (Ederington and McCalman 2008) can also help domestic firms to enhance their productivity. However, foreign competition in the final-goods market can occasionally reduce firm productivity by slowing the rate at which new technology is adopted, by reducing the domestic firm's market share (Rodrik 1992; Miyagiwa and Ohnon 1995; Ederington and McCalman 2008). Finally, productivity can also increase through a reallocation effect, where less productive domestic firms exit the market and more productive domestic firms gain their market shares (e.g. see Melitz 2003).

The knowledge spillovers between foreign and domestic firms through imported inputs could be a crucial channel (e.g. Keller 2004). In Eaton and Kortum's (1999) model, trade including imports augments the production possibilities for the classic Ricardian reasons, such as trade providing access to foreign goods or, implicitly, technologies. By specialising in their respective comparative advantage goods, countries can gain from trade in the sense that, given a country's resources, the efficient level of output with trade is higher 
than without trade. For empirical validation, a recent study by Jones (2008) has shown that in equilibrium (through the income multiplier) these channels can work and potentially enhance the level of technology, which leads to a significant improvement in productivity.

Some recent empirical studies have found a significant role for imported inputs in general, and imported intermediate goods in particular, on productivity. But overall, findings in the literature on this issue are rather mixed. The effects of importing on performance are tested in a variety of ways in the literature. We first look at the overall impact of imported inputs on productivity without considering the type of linkage that exists, vertical or horizontal. Studies of Djankov and Hoekman (2000), Bottasso and Sembenelli (2001), Halpern and Korosi (2001), Pavcnik (2002), Muendler (2004), Schor (2004) and Fernandes (2007) have estimated a positive overall impact of imports on productivity. Some others, for instance, Van Biesebroeck (2003), Muendler (2004), Halpern et al (2005), Amiti and Konings (2007), Kasahara and Rodrigue (2008), Vogel and Wagner (2010), and Goldberg et al (2010), have distinguished vertical linkages from horizontal linkages and shown positive effects of importing.

Where studies have found positive effects of firm imports or declines in input tariffs on productivity, the magnitude of the relationships found has varied considerably. For instance, on the basis of a panel of large Hungarian exporting firms, Halpern et al (2015) found that a 1 per cent increase in the share of imports raised firm productivity by 0.22 per cent, for a panel of Hungarian firm for the period 1993-2002. Amity and Konings (2007) estimated a 1 per cent reduction in input tariffs raised the TFP of importing Indonesian firms by 0.12 per cent. Using detailed trade and firm-level data from India, Goldberg et al (2010) investigated the relationship between declines in trade costs, imports of intermediate inputs, and domestic firm product scope. They estimated that substantial gains from trade had been achieved through access to new imported inputs. They also found that R\&D, output and product source are crucially dependent on the tariff rate on imported inputs. In the Chilean case, Kasahara and Rodrigue (2013) estimated that importing intermediates raised TFP substantially. Colantone and Crinò (2014) showed how new imported inputs affect the introduction of new domestic products in 25 European countries. Their findings indicated that new imported inputs had a strong positive effect on product creation. Others have shown a crucial role for importing and trade liberalisation in the transformation of economies. For instance, Lawrence and Weinstein (1999) found that lower tariffs and higher import volumes were particularly beneficial for Japan during the period 1964 to 1973 . Their findings further suggested that in the Japanese case, the salutary impact of imports stems more from their contribution to competition than to intermediate inputs.

Using a different approach, De Loecker et al (2012) examine how prices, markups and marginal costs respond to trade liberalisation in India. The 
study utilised quantity and price information to disentangle markups from quantity-based productivity, and then computed marginal costs by dividing observed prices by the estimated markups. The study findings indicated that trade liberalisation lowers factory-gate prices, and that declines in tariffs imposed on exports competing with output have the expected pro-competitive effects. Sharma (2014) also shows the important role of imported intermediate inputs on output and TFP in the selected Indian industries.

While discussing the importance of intermediate inputs for economic development, Jones (2008) concluded that they can help in explaining a large income difference across countries. Kasahara and Rodrigue (2008) argued that through adoption and imitation of imported technologies, countries can take advantage of R\&D abroad to improve the efficiency of domestic production. Their empirical analysis, using plant-level Chilean manufacturing panel data, clearly suggests that becoming an importer of foreign intermediates improves productivity. Castellani et al (2010) found that both exports and imports enhance productivity, but the positive effects of imported inputs are more important than exports, for a sample of Italian firms. Muûls and Pisu (2009) and Altomonte and Bekes (2009) have suggested that the productivity premium of exporting firms is due to the fact that they are also importing.

Focusing on the imports-productivity-export linkage, Melitz (2003) developed a dynamic industry model with heterogeneous firms to examine the intra-industry effects of international trade. The model illustrated how knowledge of trade will induce only the more productive firms to enter into export markets, and will simultaneously force the least productive firms to exit. Extending the Melitz-type model further, Kasahara and Lapham (2013) explained the simultaneous choices of firms regarding the export of final goods and import of intermediate inputs. In their model, firms produce final goods using labour and two types of intermediate inputs, domestically produced or imported. In that framework, firms importing more varieties of intermediate inputs will also have higher productivity. Using similar theoretical mechanisms, Bas and Strauss-Kahn (2014) have shown that importing more varieties of intermediate inputs might affect firm productivity and export performance. More recently, Bas and Strauss-Kahn (2015) have shown that Chinese firms exploit input tariff cuts to access high-quality inputs, in order to upgrade the quality of their exports.

The strand of literature which emphasised important channels through which importing inputs may potentially affect the firm's exporting performance has shown that import liberalisation may promote the competitiveness of domestic firms, as a reduction in input tariffs lessens the cost of imported inputs across all firms (Bas 2012). Furthermore, importing new and more advanced technology inputs enhances productivity, making firms more competitive in export markets (Halpern et al 2015). Recently, Lo Turco and Maggioni (2013) for Italian manufacturing and Aristei et al (2013) for 27 Eastern European and Central Asian countries have confirmed these channels. 
Despite a solid theoretical background and near agreement on the role of imported inputs in the literature, some empirical investigations have shown a minor role for importing. For instance, Van Biesebroeck (2003) found that productivity improvements do not happen through the use of more advanced inputs in Columbia. Similarly, Muendler (2004) reached concluded that there is only a small contribution of foreign materials and investment goods on output for Brazil. The findings of Augier et al (2013) indicated that imported inputs are important. However, the positive effects of these inputs crucially depend on firms' absorptive capacity.

By and large, the balance of findings so far is in favour of a positive effect overall. In the light of strong theoretical but mixed empirical findings, it is both relevant and interesting to explore the issue further, to determine whether the linkage exists in the Indian manufacturing sector.

\section{DATA AND TFP Estimation}

\subsection{Data}

In this study we utilise data at the level of two-digit industry groups in the Indian manufacturing sector. The data is gathered from the Prowess database provided by the Center for Monitoring Indian Economy (CMIE). Annual financial statements of firms belonging to eight industry groups, namely Food and Beverages, Textiles, Chemicals, Non-metallic Minerals, Metal and Metal Products, Machinery, Transport Equipment and miscellaneous manufacturing, have been used. Subsequently, firm-level data are transformed into industry-level data by aggregation. Industry-level data are preferred over firmlevel data for the analysis in this study, for several reasons: first, in the Prowess database, one of the most important variables for the analysis is not available. Information on compensation to workers is in the database, but data on the number of workers is missing for the majority of firms.

When industry wage rate is used (from the ASI database) to derive the number of workers for each firm (as done in many India based studies, e.g. Sharma, 2014) the derived series is generally observed to be quite inconsistent, because wage rates vary substantially among firms within an industry. This problem severely affects the results of the production function which, in turn, makes TFP results unreliable. This problem is taken care of by using industry-level data, as the industry's average wage works well in this case. Second, several studies have used firm-level data from Prowess, e.g. Goldberg et al (2010); De Loecker et al (2012) and Sharma (2014), however the main focus of the present study is on the relationship at the industry-level (aggregate -level). Using industry-level data, we are able to consider all firms (more than 15000) in the analysis, while firm-level studies have to use a much smaller sample, because of data related limitations. Finally, the main advantages of a firm-level database in analysis are the use of important information on firms such as entry-exit, competition and pricing. However, because of the very nature of The Prowess database, it does not provide this information. 
Considering these issues, we have used firms' aggregated data instead of firmlevel data.

Our analysis covers the period from 1994 to 2009. The primary reason for taking 1994 as the initial year is that the Indian economy underwent gradual structural reforms in the early 1990s, and the reforms have subsequently brought about vast changes in the manufacturing sector. Another practical reason is that the data on price indices and deflators for all variables are available only from 1994.

We use gross value added of the industries as the measure of nominal output, which is deflated by industry specific wholesale price indices (WPI) to obtain output in real terms. ${ }^{2}$ The series on real capital stock is constructed using the perpetual inventory capital adjustment method. Specifically, we compute it as:

$$
K_{t}=(1-\delta) K_{t-1}+I_{t}
$$

where, $K$ is the capital stock, $I$ is deflated gross investment, $\delta$ is the rate of depreciation taken at 7 per cent, consistent with similar studies for India (Unel 2003 and Ghosh 2009), and $t$ indicates the year. The initial capital stock equals the net book value of capital stock for the year 1994. Data on other important variables such as exports, imports and R\&D have also been extracted from the same database.

\subsection{Measuring Total Factor Productivity (TFP)}

We start our empirical analysis by estimating TFP for each industry. To this end, we follow a two-stage procedure. In the first stage, a panel of the eight industries is constructed and, following Sharma and Sehgal (2010), our CobbDouglas production function to be estimated is:

$$
\ln \left(Q_{i t}\right)=\alpha_{0}+\alpha_{1} \ln \left(K_{i t}\right)+\alpha_{2} \ln \left(N_{i t}\right)+\eta_{t}+\mu_{i t}
$$

where $Q, K$, and $N$ are the value added, the capital input and the labour input, respectively, for industry $i$ for period $t$. $\alpha_{0}$ is constant and $\alpha_{1}$ and $\alpha_{2}$ are the parameters to be estimated. The term $\eta_{t}$ represents fixed time effects, while ln represents $\log$ of the variables. The estimation of production functions in a Cobb-Douglas form of a panel data is a challenging task. Griliches and Mairesse (1995) have shown that OLS regressions yield plausible parameter estimates, in line with evidence from factor shares, which is mostly consistent with constant returns to scale. But problems of unobserved heterogeneity and simultaneity - both likely to lead to bias in the OLS results - yield potentially less satisfactory parameter estimates. In other words, observed inputs likely to be correlated with unobserved shock and therefore OLS will yield biased and inconsistent estimates. Initially the GMM estimator is proposed to overcome these problems. The estimator takes first differences to eliminate unob- 
served effects and uses lagged instruments to correct the simultaneity. However, Mairesse and Hall (1996) have shown that this method often provides unsatisfactory results in production function estimations. This is primarily because weak instruments could cause large finite-sample biases when using the first-differenced GMM procedure (see Blundell and Bond 1998). Blundell et al (2000) showed that use of Sys GMM could dramatically reduce biases, as it incorporates more informative moment conditions that are valid under quite reasonable stationarity restrictions on the initial conditions process. Bond et al (2003) and Blundell and Bond (1998) have shown that the additional moment restrictions exploited by the Sys GMM estimator appear to be valid, and they appear to be useful reducing finite-sample biases associated with first-differenced GMM.

It is noteworthy that in the recent related literature, several other potential biases in the production function and their solutions are also discussed. For instance, the estimation of true productivity is confounded by demand shocks and markup, and sometimes these biases are quite significant (see Foster et al 2008). Furthermore, De Loecker (2011) has shown that controlling for demand shocks can substantially improve the accuracy of productivity estimates and he addressed the bias arising from unobserved output prices, by using a constant elasticity of substitution (CES) demand system. De Loecker et al (2012) have addressed the problem by using prices and quantities of firms' products over time. Moreover, biases stemming from inputs products within multi-product firms, and bias stemming from unobserved input prices, are also highlighted by De Loecker et al (2012). In our analysis, we acknowledge that these issues are by and large ignored, because of various reasons including data constraints. Nevertheless, the potential biasness should not be significantly large in our case as we are using industry level data instead of plant or firm data. Furthermore, application of Sys-GMM and sectoral price deflators (in transforming the variables) should also address these biases, to an extent.

Results of the production function are reported in Table 1. Column 1 of the table reports results of the fixed effect estimator, while column 2 reports results of the production function using Sys-GMM. Both results indicate that elasticity of labour and capital are statistically significant and somewhat similar. For TFP computation purposes, we use estimated coefficients of the SysGMM estimator.

Utilising the production results of equation 2, we calculate TFP of the sample industries as:

$$
\ln \left(T F P_{i t}\right)=\ln \left(Q_{i t}\right)-\hat{\alpha}_{1} \ln \left(K_{i t}\right)-\hat{\alpha}_{2} \ln \left(N_{i t}\right)
$$

where $\hat{\alpha}_{1}$ and $\hat{\alpha}_{2}$ are the estimated parameters of capital and labour, respectively ) see colmun 2 of table 1 ). 
Table 1. Cobb- Douglas Production Function Estimation, 1994-2009 (Dependent Variable: In(GVA))

\begin{tabular}{ccc}
\hline Variables & $\begin{array}{c}\text { Coefficients } \\
(1)\end{array}$ & $\begin{array}{c}\text { Coefficients } \\
(2)\end{array}$ \\
& $0.44^{* *}$ & $0.42^{* *}$ \\
$\ln (\mathrm{K})$ & $(0.025)$ & $(0.021)$ \\
& $0.49^{* *}$ & $0.43^{* *}$ \\
$\ln (\mathrm{N})$ & $(0.054)$ & $(0.012)$ \\
Const & -.004 & -0.011 \\
GVA(-1) & $(0.12)$ & $(0.074)$ \\
& & $0.22^{* *}$ \\
$\mathrm{R}^{2}$ & 0.97 & $(0.042)$ \\
& & \\
Estimator & Fixed Effect & Sys-GMM \\
Notes: Standard errors are in parentheses. ${ }^{* *}$ denotes significant at $5 \%$ critical level.
\end{tabular}

\section{EMPIRICAL MOdELS AND ECONOMETRIC ISSUES}

\subsection{Empirical Models}

To test the effects of imported inputs, we test two empirical models. The first model is to test the effects of imported inputs on the productivity (TFP) of industries, while the second model examines the effects on export performance of Indian manufacturing industries. These models are as follows:

$$
\begin{gathered}
\ln \left(T F P_{i t}\right)=\alpha_{1}+\alpha_{2} \ln (\operatorname{Import})+\alpha_{3} \ln \left(X_{i t}\right)+e_{i t} \\
\ln \left(\text { Expor }_{i t}\right)=\beta_{1}+\beta_{2} \ln \left(\mathrm{TFP}_{i t}\right)+\beta_{3} \ln (\operatorname{Impor} t)+\beta_{4} \ln \left(X_{i t}\right)+\varepsilon_{i t}
\end{gathered}
$$

where TFP, Export and Import are TFP, export intensity (total export/industrial sales) and import intensity (total import/industrial sales), respectively in industry $i$ at year $t$. $X$ represents two control variables of industries that we consider : R\&D intensity (R\&D expenditure/ industrial sales) and size (proxied by deflated value of industrial Sales). All variables are converted into logs. Equation 4 tests the role of imported inputs on TFP, after controlling for the effects of size and innovation activities. The second model (equation 5) tests the extent to which imported inputs benefit exporting activities. The model controls for productivity, size and innovative activities.

\subsection{Econometrics issue}

We focus here on the issue of estimating equations 4 and 5 . In the related literature, a number of issues arise relating to application of estimators. These include spurious correlation due to non-stationary data, omitted variables, endogeneity and reverse causality, which may lead to biased estimation of the 
coefficients. To attempt to overcome the issue of non-stationarity some researchers, for instance, Hulten and Schwab (1991), used first differences. However, this could be costly as it may remove the long-run characteristics of the variables of interest, with a substantial loss of information. Moreover, it is highly likely that the short-term properties are quite different from the longterm ones.

Some researchers, for example Holtz-Eakin (1994), have used the fixed-effects (FE) estimator for the analysis. The advantage of the FE estimator is that it can handle the issue of omitted variables. FE also somewhat helps in alleviating the adverse consequences of endogeneity bias. Furthermore, to some extent, this estimation method addresses non-stationarity as well because in the 'within' form, deviations from the mean are used in the estimation. Another method which could be useful in the presence of heterogeneity and contemporaneous correlation is Sys-GMM. As discussed in the previous section, this estimator uses extra moment conditions that rely on certain stationarity conditions of the initial observation. When these conditions are satisfied, the resulting Sys-GMM estimator has been shown in Monte Carlo studies by Blundell and Bond (1998) and Blundell et al (2000) to have much better finite sample properties, in terms of bias and root mean squared error. Another option is to retain the long-run properties of the series, following Canning and Pedroni (2008), Fedderke and Bogetiæ(2009) and Sharma and Sehgal (2010), who apply panel co-integration techniques and establish a long-run relation among panel variables.

After establishing that there is a linear combination between variables that keeps the pooled variables in proportion to one another in the long run, our next step could be to estimate the cointegration equation for both models, using the FMOLS developed by Pedroni (1999, 2001). Pedroni (1999) havsshown that with the use of FMOLS on a properly constructed model, the asymptotic distributions for these estimators can be made to be centered around the true value and are likely to be free of nuisance parameters. Furthermore, based on Monte Carlos simulations, it can be shown that, in particular, the t-statistic constructed from the between dimension group means the estimator performs very well for a relatively small sample size. We, therefore, apply the aforementioned methodologies in this study, to check the consistency and robustness of the estimates.

\section{EMPIRICAL RESULTS}

A preliminary step in our approach involves testing for the stationarity of the series used in equations 4 and 5 . This has been done using the cross-sectional Im-Pesaran-Shin (CIPS) panel unit-root test, which is based on the simple averages of the individual cross-sectional augmented Dickey-Fuller statistics. The main advantages of this approach are that it incorporates potential crosssectional dependence and it does not pool directly the autoregressive parameter in the unit root regression. Thus, it allows for the possibility of heteroge- 
neous coefficients of the autoregressive parameters under the alternative hypothesis that the process does not contain a unit root. The results of the unit root test are reported in Table 2. For all individual series the hypothesis of a unit root cannot be rejected at the level form, but it is rejected convincingly in the first difference form.

Table 2: Test for Panel Unit Root Applying Im-Pesaran-Shin (CIPS) W-statistics

\begin{tabular}{lrc}
\hline Variables & At Level & At 1st Difference \\
TFP & 0.12202 & $-3.04503^{* *}$ \\
EXPORT & 0.19247 & $-5.96662^{* *}$ \\
IMPORT & -0.19036 & $-7.97863^{* *}$ \\
RNDINT & 1.01247 & $-2.39198^{* *}$ \\
Size & -1.22424 & $-2.73512^{* *}$ \\
& Notes: ** denotes significance at $5 \%$ \\
\hline
\end{tabular}

If the data generating process for the variables is characterised by panel unit roots, it is crucial to test for cointegration in a panel perspective. We apply Pedroni's (1999) test, an extension of the Engle-Granger construction, to test the existing cointegration relationship. Two types of tests have been suggested by Pedroni. The first is based on the 'within dimension' approach, which pools the autoregressive coefficients across different members for the unit root tests on the estimated residuals. The second test is based on the 'betweendimension' approach, which are based on estimators that simply average the individually estimated coefficients for each member. We calculate heterogeneous panel cointegration as well as heterogeneous group mean panel cointegration statistics for equations 4 and 5 . These results provide support for a cointegrating relationship among variables in both models. ${ }^{3}$

As explained earlier, after establishing a linear combination between variables that keeps the pooled variables in proportion to one another in the long run, our next step is to estimate the cointegration equation for both models. Because OLS estimators are biased and inconsistent when applied to cointegrated panels, we utilise the 'group-mean' panel FMOLS estimator. ${ }^{4}$ The estimator corrects the standard pooled OLS for serial correlation and endogeneity of regressors that are normally present in long-run relationship. It is noteworthy that in this study we are not interested in reverse causality, therefore we restrict our focus to an estimation of equations 4 and 5 .

Results of the estimation of equation 4 are reported in Table 3. Overall, the results suggest that imported inputs are a determinant of TFP, as the elasticity is estimated to be around 0.07, which indicates that a 1 per cent increase in imported inputs leads to a 0.07 per cent increase in the TFP of manufacturing firms in India. However, the impact varies greatly across industries. The TFP of Metal and Metal products, Food and Beverage, 
Machinery and Textile industries are heavily dependent on imports, while in other industries the effects are either minimal or statistically insignificant. The result regarding Metal and Metal products is quite large (0.23), which makes sense as these firms, including from iron and steel, are heavily dependent on quality imported inputs. Surprisingly, however, for Transport equipment (which includes Automobiles) and Chemicals (which includes Drug and Pharmaceuticals) the coefficients are not statistically significant. Bas and Strauss-Kahn (2014) have estimated quite similar results for French industries. Specifically, they have found 0.068 per cent to 0.096 per cent effects on TFP when imported inputs increased by 1 per cent, while in the Indian case, we have estimated it to be 0.07 per cent.

Another important result concerns R\&D intensity, with in-house R\&D activities not playing any significant role in the productivity performance of Indian manufacturing. This is in line with the earlier findings of Sharma and Mishra (2011) and Sharma (2012) for Indian manufacturing.

Table 3: FMOLS Result: Effects of Imported Intermediary Inputs on TFP, 1994-2009

\begin{tabular}{llll}
\hline Industry & Import-Raw & Output & RNDINT \\
Chemical & -0.004803 & 0.740172 & 0.067880 \\
& $(-0.138)$ & $(1.1205)$ & $(1.1243)$ \\
Food and Beverage & $0.193015^{* *}$ & -3.454734 & 0.058214 \\
Machinery & $(2.158)$ & $(-0.7271)$ & $(1.079)$ \\
& 0.123470 & -0.407117 & 0.002546 \\
Metal \& metal products & $(0.841)$ & $(-0.3123)$ & $(0.0311)$ \\
Non metallic mineral products & $0.2298^{* *}$ & $1.937868^{* *}$ & -0.007070 \\
& $(5.4005)$ & $(3.7422)$ & $(-0.2679)$ \\
Textile & 0.007168 & $4.463531^{* *}$ & -0.033993 \\
Transport equipment & $(-0.2679)$ & $(2.1536)$ & $(-1.3653)$ \\
Miscellaneous manufacturing & $0.090379^{* *}$ & $1.144505^{* *}$ & 0.002404 \\
& $(1.957)$ & $(2.8062)$ & $(0.2637)$ \\
Overall & -0.035368 & $0.410490^{* *}$ & 0.023554 \\
& $(-1.1844)$ & $(2.1724)$ & $(0.2637)$ \\
Notes: & $(1.5207)$ & 1.649393 & 0.067323 \\
1. ** and * denote significant at $5 \%$ and 10\% critical level respectively. & \\
2. t-statistics in parentheses. & & $(1.1999)$ & $(1.1162)$ \\
\hline
\end{tabular}

The previous empirical literature has mainly tested import-export cost complementarities and the export-enhancing effect of imports, which work through productivity gains (e.g. Bas and Strauss-Khan 2011; Kasahara and Lapham 2013). In the next stage, we attempt to test the direct effects of 
importing on exporting performance. To this end, we have estimated Equation 5 and report results in Table 4 . Results suggest the import elasticity is quite large (0.43), thus a 1 per cent increase in imports leads to 0.43 per cent growth in exports. This link is especially strong for exports in the Chemical, Machinery and Transport equipment industries. This is indeed an important finding for policy perspectives. The results also indicate that although $R \& D$ is not linked with the productivity of industries, it has an important role in the export performance of these industries.

TFP is also estimated to have a significant and sizable association with export performance. This supports the self-selection hypothesis, which explains the self-selection of more productive firms into the export market. The magnitude of the estimated relationships are relatively large when compared with the findings of previous studies for other countries, for instance, Lo Turco and Maggioni (2013) for Italy, which has estimated a much lower coefficient. Previous studies on India, for instance Sharma and Mishra (2011), have shown a minor effect of exporting on productivity but a noticeable effect of reverse causality. Thus one can conclude exporting and importing share complementarity, with both affecting the productivity of firms significantly.

Table 4: FMOLS Result: Effects of Imported Inputs on Exports, 1994-2009

\begin{tabular}{lcccc}
\hline Industry & Import & Size & RNDINT & TFP \\
& & & & \\
Chemical & $0.58024^{* *}$ & 0.149886 & $0.796764^{* *}$ & -0.974615 \\
& $(2.528)$ & $(0.832)$ & $(3.272)$ & $(-1.096)$ \\
Food and Beverage & -0.032527 & -0.101435 & 0.022434 & $0.597837^{* *}$ \\
& $(-0.919)$ & $(-1.146)$ & $(0.824)$ & $(2.279)$ \\
Machinery & $1.38057^{* *}$ & $0.20570^{* *}$ & $0.426776^{* *}$ & 0.703451 \\
& $(6.602)$ & $(2.299)$ & $(3.918)$ & $(1.362)$ \\
Metal \& metal products & -0.09956 & $0.753364^{* *}$ & 0.096431 & 0.780521 \\
& $(-0.374)$ & $(2.139)$ & $(0.931)$ & $(0.567)$ \\
Non metallic mineral products & $0.55358^{* *}$ & -0.093055 & 0.013441 & $2.867779 * *$ \\
& $(5.828)$ & $(-0.582)$ & $(0.518)$ & $(4.496)$ \\
Textile & -0.204325 & $0.317212^{* *}$ & 0.006157 & 0.300186 \\
& $(-1.797)$ & $(5.181)$ & $(0.313)$ & $(0.418)$ \\
Transport equipment & $0.798121^{* *}$ & $0.271168^{* *}$ & 0.059928 & -2.712648 \\
& $(5.828)$ & $(2.518)$ & $(0.627)$ & $(-1.676)$ \\
Miscellaneous manufacturing & 0.492151 & -0.394143 & -0.050884 & 0.166357 \\
& $(1.091)$ & $(-0.689)$ & $(-0.331)$ & $(0.103)$ \\
Overall & $0.433532 * *$ & $0.138587 * *$ & $0.171381^{* *}$ & $0.216108^{* *}$ \\
& $(6.642)$ & $(3.731)$ & $(3.561)$ & $(2.282)$ \\
Notes: & & & & \\
1. ** and * denote significant at & $5 \%$ and $10 \%$ critical level respectively. & \\
2. t-statistics in parentheses. & & & & \\
\hline
\end{tabular}


To test the robustness of the FMOLS results, we re-estimated Equations 4 and 5 using OLS fixed effects and Sys-GMM. The results are reported in Table 5. Columns 1 and 3 report the results in which TFP is the dependent variable and the model is estimated using fixed effect and Sys-GMM, respectively. The estimated coefficients of imported raw materials are 0.077 and 0.054 which is quite close to the FMOLS results. Furthermore, findings on R\&D are again found to be insignificant. Focusing on results in column 2 of Table 5, fixed effect estimates indicate that imported inputs effects are 0.31 per cent. However, Sys-GMM results provide a moderate size (0.092) of effects on export performance. Importantly, the Sys-GMM results also confirm positive effects for R\&D efforts on export performance. Overall, these results endorse our FMOLS based estimated results.

Table 5: Robustness Check: Effects of Imported Inputs on TFP and Export, 1994-2009

\begin{tabular}{|c|c|c|c|c|}
\hline Industry & $\begin{array}{l}\text { Dependent } \\
\text { Variable-TFP } \\
\quad \text { (1) }\end{array}$ & $\begin{array}{l}\text { Dependent } \\
\text { Variable-Export } \\
\text { (2) }\end{array}$ & $\begin{array}{l}\text { Dependent } \\
\text { Variable-TFP } \\
\text { (3) }\end{array}$ & $\begin{array}{l}\text { Dependent } \\
\text { Variable-Export } \\
\text { (4) }\end{array}$ \\
\hline Import & $\begin{array}{l}0.0774007^{* *} \\
(2.69)\end{array}$ & $\begin{array}{l}0.3118253^{* *} \\
(4.19)\end{array}$ & $\begin{array}{l}0.0549159 * * \\
(2.83)\end{array}$ & $\begin{array}{l}0.0927318^{* *} \\
(2.06)\end{array}$ \\
\hline Size & $\begin{array}{c}0.6753878^{* *} \\
(31.96)\end{array}$ & $\begin{array}{l}-0.3289995^{* *} \\
(-1.99)\end{array}$ & $\begin{array}{l}0.4890057^{* *} \\
(15.37)\end{array}$ & $\begin{array}{c}-0.1070502 \\
(-1.34)\end{array}$ \\
\hline RNDINT & $\begin{array}{c}-0.0203007 \\
(-1.66)\end{array}$ & $\begin{array}{l}0.0230971 \\
(0.75)\end{array}$ & $\begin{array}{l}0.0022485 \\
(0.27)\end{array}$ & $\begin{array}{l}0.0378972 * * \\
(2.23)\end{array}$ \\
\hline TFP & & $\begin{array}{l}1.047218 \text { ** } \\
(4.52)\end{array}$ & & $\begin{array}{c}0.192286 \\
(1.63)\end{array}$ \\
\hline & & & $\begin{array}{l}0.3468024 * * \\
(7.76)\end{array}$ & 0.8180675 \\
\hline Export(-1) & & & & $(18.15)$ \\
\hline Constant. & $\begin{array}{c}-0.524892^{* *} \\
(-7.10)\end{array}$ & $\begin{array}{c}-0.2606437 \\
(-1.18)\end{array}$ & & $\begin{array}{r}92.36612 \\
(0.6141)\end{array}$ \\
\hline $\begin{array}{l}\text { Sargan } \chi^{2} \\
\text { (P-value) }\end{array}$ & & & $\begin{array}{l}262.3476 \\
(0.00)\end{array}$ & \\
\hline $\mathrm{R}^{2}$ & 0.9214 & 0.6025 & & \\
\hline Estimator & Fixed & Fixed & Sys-GMM & Sys-GMM \\
\hline \multicolumn{5}{|c|}{$\begin{array}{l}\text { Notes: } \\
\text { 1. ** denotes significant at } 5 \% \text { critical level. } \\
\text { 2. t-statistics in parentheses. } \\
\text { 3. Sargan is the Sargan (1958) test of over-identifying restrictions }\end{array}$} \\
\hline
\end{tabular}

\section{Conclusion and Policy Suggestions}

There is a voluminous empirical literature available on industrial performance and exports, however, much less consideration has been given to the import behaviour and firm or industry characteristics. Even fewer analyses consider the linkage between import and export activities. This is unfair, given the 
strong association between importing and exporting and the key role of imports in the world economy. In order to fill these gaps, in this study we have tested the effects of import intermediate inputs on productivity. We have also analysed the role of imported inputs on the export performance of manufacturing industries.

Our results indicate that imported intermediate goods are crucial determinants of TFP. However, it is noteworthy the impact varies greatly across industries. The TFP of Metal and Metal products, Food and Beverage, Machinery and Textile industries are heavily dependent on imports, while in other industries the effects are minimal. Furthermore, the results regarding $R \& D$ intensity suggest that in-house $R \& D$ activities do not play a significant role in the productivity performance of Indian manufacturing. Nevertheless, in some industries, R\&D intensity has a significant impact on export performance. This may be an indication that $R \& D$ activities mainly focus on export gain.

Our results also confirm that imported inputs lead to a substantial growth in exports. Exports by the Chemical, Machinery and Transport equipment industries in particular are highly dependent on imported inputs. This is indeed an important finding from a policy perspective. The results also indicate that although $R \& D$ is not linked significantly with the productivity of industries, it has an important role in the export performance of these industries. TFP is also estimated to be significantly related to export performance. This supports the self-selection hypothesis, which explains the self-selection of more productive firms into export markets. These results indicate that imported inputs are crucial for both productivity and exporting. Therefore, it seems that imported inputs provide competitiveness to firms in terms of quality as well as cost, as it affects exports directly, as well as indirectly through productivity channels.

Accepted for publication: 14 December 2015

\section{ENDNOTES}

1. Indian Institute of Management, Lucknow, India, Pin: 201307, Email: chandanieg@gmail.com. Address for communication: Indian Institute of Management Lucknow, Noida Campus, B-1, Sector-62, Noida 201307, INDIA. Office-Phone: 91-1206678488. The author thanks the anonymous referees and submission editor of this journal, Piers Thompson, for their useful comments and helpful suggestions on previous versions of this paper. Any errors or omissions are solely of the authors.

2. We use gross value added as a measure of output in the production function for computing TFP. There are many advantages of using gross value added over output. First, it makes it possible to compare between firms that use different raw materials. Second, if gross output is used as a measure of output, it adds the necessity of including raw materials, which may obscure the role of labour and capital in productivity growth (Hossain and Karunaratne 2004; Kumar, 2006). 
3. These results are not reported because of space constraints. They will be provided on request to the author.

4. We have applied 'group-mean FMOLS', because we have a small sample for the analysis. Pedroni $(2000,2001)$ has shown that the 'group-FMOLS' has relatively lower small sample distortions and more flexibility in terms of hypothesis testing than the other three versions of FMOLS (see also Basher and Mohsin 2004).

5 . The reason behind this hypothesis is the presence of sunk costs when entering and selling goods in foreign markets. See Sharma and Mishra (2011) for details.

\section{REFERENCES}

Altomonte C and Bekes G (2009) 'Trade Complexity and Productivity', IEHAS Discussion Papers 0914, Institute of Economics, Centre for Economic and Regional Studies, Hungarian Academy of Sciences, Hungary.

Amiti M and Konings $\mathrm{J}$ (2007) 'Trade liberalization, intermediate inputs and productivity: Evidence from Indonesia', American Economic Review, 97(5), 1611-1638.

Anós-Casero P and Astarloa B D (2010) 'Estimating the Import Content of Argentine Exports', Policy Research Working Paper 5225, The World Bank: Latin America and the Caribbean Region Economic Policy Sector.

Aristei D, Castellani D and Franco C (2013) 'Firms' exporting and importing activities: is there a two-way relationship?', Review of World Economics, 149(1), 55-84.

Augier P, Cadot O and Dovis M (2013) 'Imports and TFP at the firm level: The role of absorptive capacity', Canadian Journal of Economics, 46(3), 956-981.

Barro R J (1997) Determinants of Economic Growth, Cambridge MA: MIT Press.

Bas M (2012) 'Input-trade liberalization and firm export decisions: Evidence from Argentina', Journal of Development Economics, 97(2), 481-493.

Bas M and Strauss-Kahn V (2014) 'Does importing more inputs raise exports? Firm level evidence from France', Review of World Economics, 150(2), 241-275.

Bas M and Strauss-Kahn V (2015) 'Input-trade liberalization, export prices and quality upgrading', Journal of International Economics, 95(2), 250-262.

Basher S A and Mohsin M (2004) 'PPP tests in cointegrated panels: evidence from Asian developing countries', Applied Economics Letters, 11(3), 163-166.

Bernard A B, Eaton J, Jensen J B and Kortum S (2003) 'Plants and productivity in international trade', American Economic Review, 93(4), 1268-1290.

Bhanumurthy N R and Sharma C (2013) 'Does Weak Rupee Matter for India's Manufacturing Exports?', Working Papers 13/115, National Institute of Public Finance and Policy, New Delhi.

Blundell R and Bond S (1998) 'Initial conditions and moment restrictions in dynamic panel Business Services Enterprises', Applied Economics Quarterly, 56(1), 7-30.

$$
-17-
$$


Blundell R, Bond S and Windmeijer F (2000) 'Estimation in dynamic panel data models: improving on the performance of the standard GMM estimator', IFS Working Papers W00/12, Institute for Fiscal Studies, London.

Bond S, Harhoff D and Van Reenen J (2003) 'Investment, R\&D and financial constraints in Britain and Germany', Working Paper 595. Centre for Economic Performance, London School of Economics and Political Science, London.

Bottasso A and Sembenelli A (2001) 'Market power, productivity and the EU single market program: evidence from a panel of Italian firms', European Economic Review, 45, 167-186.

Canning D and Pedroni P (2008) 'Infrastructure, Long-Run Economic Growth And Causality Tests For Cointegrated Panels', Manchester School, 76(5), 504-527.

Castellani D, Serti F and Tomasi C (2010) 'Firms in International Trade: Importers' and Exporters' Heterogeneity in Italian Manufacturing Industry', The World Economy 33(3), 424-457.

Coe D T and Helpman E (1995) 'International R\&D spillovers', European Economic Review, 39(5), 859-887.

Colantone I and Rosario C (2014) 'New imported inputs, new domestic products', Journal of International Economics, 92(1), 147-165.

De Loecker J (2011) 'Product Differentiation, Multi-Product Firms and Estimating the Impact of Trade Liberalization on Productivity', Econometrica, 79(5), 1407-1451.

De Loecker J, Goldberg P, Khandelwal A and Pavcnik N (2012) 'Prices, Markups and Trade Reform', NBER Working Paper w17925, National Bureau of Economic Research, Cambridge MA.

De Loecker J and Warzynski F (2012) 'Markups and Firm-level Export Status', American Economic Review, 102(6), 2437-2471.

Djankov S and Hoekman B (2000) 'Market discipline and corporate efficiency: evidence from Bulgaria', Canadian Journal of Economics, 33, 190-212.

Eaton J and Kortum S (1999) 'International Patenting and Technology Diffusion: Theory and Measurement', International Economic Review, 40, 537-70.

Ederington J and McCalman P (2008) 'Endogenous firm heterogeneity and the dynamics of trade liberalization', Journal of International Economics, 74, 422-440.

Ethier W J (1982) 'National and international returns to scale in the modern theory of international trade', American Economic Review, 72(3), 389-405.

Fedderke J W and Bogeti? Z (2009) 'Infrastructure and Growth in South Africa: Direct and Indirect Productivity Impacts of 19 Infrastructure Measures', World Development, 37(9), 1522-1539.

Fernandes A M (2007) 'Trade policy, trade volumes and plant-level productivity in Colombian manufacturing industries', Journal of International Economics, 71, 52-71.

Foster L S, Haltiwanger J and Syverson C (2008) 'Reallocation, Firm Turnover, and Efficiency: Selection on Productivity or Profitability?', American Economic Review, 98(1), 394-425. 
Frankel J A and Romer D (1999) 'Does trade cause growth?', American Economic Review, 89(3), 379-399.

FTP (2009) 'Foreign Trade Policy (27th August 2009 - 31st March 2014)', Government of India, Ministry of Commerce and Industry, Department of Commerce (Online available: http://pib.nic.in/archieve/foreigntradepolicy/foreigntradepolicy.pdf)

Ghosh S (2009) 'Do productivity and ownership really matter for growth? Firm-level evidence', Economic Modelling, 26, 1403-1413.

Ghosh B and De P (2004) 'How do different categories of infrastructure affect development? Evidence from Indian states', Economic and Political Weekly, 39(42), 4645-4657.

Goldberg P, Khandelwal A, Pavcnik N and Topalova P (2010) 'Imported intermediate inputs and domestic product growth: Evidence from India', Quarterly Journal of Economics, 125(4), 1727-1767.

Griliches, Z and Mairesse J (1995) 'Production Functions: The Search for Identification', Harvard Institute of Economic Research Working Papers 1719, Harvard, Cambridge, MA.

Halpern L, Koren M and Szeidl A (2005) 'Imports and productivity', CEPR Discussion Papers 5139, London.

Halpern L, Koren M and Szeidl A (2015) Imported Inputs and Productivity, available online at http://www.personal.ceu.hu/staff/Adam_Szeidl/papers/imports_productivity.pdf

Halpern L and Korosi G (2001) 'Efficiency and market share in the Hungarian corporate sector', Economics of Transition 9, 559-592.

Helpman, E and Krugman P R (1985) Market Structure and Foreign Trade: Increasing Returns, Imperfect Competition, and the International Economy, Cambridge MA: MIT Press.

Herander M G and Thomas C R (1986) 'Export performance and export-import linkage requirements', Quarterly Journal of Economics, 101, 591-607.

Holtz-Eakin D (1994) 'Public sector capital and the productivity puzzle', Review of Economics and Statistics, 76(1), 12-21.

Horn H, Lang H and Lundgren S (1995) 'Managerial effort incentives, X-inefficiency and international trade', European Economic Review, 39(1), 117-138.

Hossain M A and Karunaratne N D (2004) 'Trade liberalization and technical efficiency: evidence from Bangladesh manufacturing industries', The Journal of Development Studies, 40(3), 87-114.

Hulten C R and Schwab R M (1991) 'Is there too little public capital? Infrastructure and economic growth', paper presented at the American Enterprise Institute Conference: 'Infrastructure Needs and Policy Options for the 1990s', Washington DC, 4 February.

Hummels D, Ishii J and Kei-Mu Y (2001) 'The nature and growth of vertical specialization in world trade', Journal of International Economics, 54, 75-96.

Jones C I (2008) 'Intermediate goods and weak links: A theory of economic development', NBER Working Paper No. 13834, National Bureau of Economic Research, Cambridge MA.

$$
-19-
$$


Kasahara H and Lapham B (2013) 'Productivity and the decision to import and export: theory and evidence', Journal International Economics, 89, 297-316.

Kasahara H and Rodrigue J (2008) 'Does the use of imported intermediates increase productivity? plant-level evidence', Journal of Development Economics, 87(1), 106-118.

Keller W (2004) 'International technology diffusion', Journal of Economic Literature, 42(3), 752-782.

Krugman P (1979) 'Increasing returns, monopolistic competition, and international trade', Journal of International Economics, 9(4), 469-479.

Kumar S (2006) 'A decomposition of total productivity growth: a regional analysis of Indian industrial manufacturing growth', International Journal of Productivity and Performance Management, 55, 311-331.

Lawrence R Z and Weinstein D E (1999) 'Trade and Growth: Import-Led or Export-Led? Evidence From Japan and Korea', NBER Working Papers 7264, National Bureau of Economic Research, Cambridge MA.

Lo Turco A and Maggioni D (2013) 'On the Role of Imports in Enhancing Manufacturing Exports', The World Economy, 36(1), 93-120.

Mairesse J and Hall H B (1996) 'Estimating the Productivity of Research and Development: An Exploration of GMM Methods Using Data on French \& United States Manufacturing Firms', NBER Working Papers 5501, National Bureau of Economic Research, Cambridge MA.

Melitz M J (2003) 'The impact of trade on intra-industry reallocations and aggregate industry productivity', Econometrica, 71, 1695-1725.

Miyagiwa K and Ohnon Y (1995) 'Closing the technology gap under protection', American Economic Review, 85, 755-770.

Muendler M A (2004) 'Trade, Technology, and Productivity: A Study of Brazilian Manufacturers, 1986-1998', CESifo Working Paper Series No. 1148. Munich: CESifo Group.

Muûls M and Pisu M (2007) 'Imports and Exports at the Level of the Firm: Evidence from Belgium', The World Economy, 32(5), 692-734.

Pavcnik N (2002) 'Trade liberalisation, exit, and productivity improvements: evidence from Chilean plants', Review of Economic Studies, 69, 245-276.

Pedroni P (1999) 'Critical values for cointegration tests in heterogeneous panels with multiple Regressors', Oxford Bulletin of Economics and Statistics, S (61), 653-670.

Pedroni P (2000) 'Fully Modified OLS for Heterogeneous Cointegrated Panels', Advances in Econometrics, 15, 93-130.

Pedroni P (2001) 'Purchasing power parity in cointegrated panels', The Review of Economics and Statistics, 83(4), 727-731.

Rivera-Batiz L A and Romer P (1991) 'Economic integration and endogenous growth', Quarterly Journal of Economics, 106, 531-555.

Rodrik D (1992) 'Closing the Productivity Gap: Does Trade Liberalisation Really Help?' 
in Helleiner G K (ed) Trade Policy, Industrialisation and Development: New Perspectives, Oxford: Clarendon Press, 155-175.

Romer, P (1987) 'Growth based on increasing returns due to specialization', American Economic Review, 77(2), 56-62.

Sargan, J D (1958) 'The Estimation of Economic Relationships Using Instrumental Variables', Econometrica, 26, 393-415.

Schor A (2004) 'Heterogeneous productivity response to tariff reduction. Evidence from Brazilian manufacturing firms', Journal of Development Economics, 75, 373-396.

Sharma C (2012) 'R\&D and firm performance: evidence from the Indian pharmaceutical industry', Journal of the Asia Pacific Economy, 17(2), 332-342.

Sharma C (2014) Imported Intermediate Inputs, R\&D, and Productivity at Firm Level: Evidence from Indian Manufacturing Industries', The International Trade Journal, 28(3), 246-263.

Sharma C and Mishra R K (2011) Does export and productivity growth linkage exist? Evidence from the Indian manufacturing industry', International Review of Applied Economics, 25(6), 633-652.

Sharma C and Sehgal S (2010) 'Impact of infrastructure on output, productivity and efficiency: evidence from the Indian manufacturing industry', Indian Growth and Development Review, 3, 100-121.

Topalova P (2011) 'Trade Liberalization and Firm Productivity: The Case of India', The Review of Economics and Statistics, 93(3), 995-1009.

Unel B (2003) 'Productivity trends in India's manufacturing sectors in the last two decades', IMF Working Paper No. 03/22, International Monetary Fund.

Van Biesebroeck J (2003) 'Revisiting some productivity debates', NBER Working Paper 10065, National Bureau of Economic Research, Cambridge MA.

Vogel A and Wagner J (2010) Exports and Profitability - First Evidence for German Business Services Enterprises, Applied Economics Quarterly, 56(1), 7-30.

Wonnacott P and Wonnacott R (2005) 'What's the Point of Reciprocal Trade Negotiations? Exports, Imports, and Gains from Trade', The World Economy, 28(1), 120. 